\title{
THE APPLICATION OF PICTURES AND PEER ASSESSMENT FOR TEACHING DESCRIPTIVE TEXT IN WRITING CLASS
}

\author{
Received: $23-10-2017$
}

\author{
Komang Dian Puspita Candra \\ STIBA Saraswati Denpasar \\ miss_puspita@yahoo.com
}

Revised: 28-10-2017

Accepted: 06-11-2017

How to Cite: Candra, P. (2017) The Application of Pictures and Peer Assessment for teaching Descriptive

Text in Writing Class. RETORIKA: Jurnal Ilmu Bahasa 3(2). 271-280

DOI: $10.22225 / \mathrm{jr} .3 .2 .342 .271-280$

\begin{abstract}
English has four basic language skills those are listening, writing, reading and speaking. Teaching English at Junior high school is based on the school based curriculum. In competence based curriculum, students should be able to produce written texts based on certain genres, and one of them is descriptive text. Based on the observation, the ability of students in seventh grade of SMP Pemecutan Denpasar, in making descriptive text is lower than the other genres. Students feel bored in writing class and get stuck in describing something. Because of these difficulties, some efforts have been done to solve the problems. One of them is by teaching writing especially for descriptive text by using pictures and combined it with peer assessment. This study is intended to improve the ability of seventh grade students of SMP Pemecutan Denpasar in writing descriptive text. This study was designed in the form of classroom action research to 17 students that consists of two cycles and involving four steps in each cycle namely planning, action, observation and reflection. In order to collect the data, three instruments were used those are test, observation and questioner. The data were analyzed qualitative and quantitative based on rubric proposed by Brown (1994) and Nurgiyantoro (2010). The data analyses were presented in the table and chart as well as also in descriptive narrative sentences. The result of this study showed that the implementing of pictures and peer assessment could improve the ability of students in writing descriptive text. It can be seen from the mean score of students was 58 in pretest and after conducting the treatment in the first cycle the student's mean score improved to 71 and become 77 in second cycle. There are 5 students $(29,41 \%)$ who passed the KKM in pre test and there is a significant increasing in first cycle becomes 12 students $(70,58 \%)$ and all students $(100 \%)$ passed the KKM in second cycle. It can be inferred that the combination of pictures and peer assessment was very effective helping the students in writing a descriptive text and build their motivation in writing class.
\end{abstract}

Keywords: Pictures, Peer Assessment, Teaching Writing, Descriptive Text

\section{INTRODUCTION}

English subject is given to all formal education levels. Therefore, English's standard competency is needed to be sufficient and effective. Teaching English at Junior high school is based on the school based curriculum. Writing is one of the language skills that should be taught besides the other skills. In competence based curriculum, students should be able to produce written texts based on certain genres, one of them they should create a descriptive text. Descriptive text is the text which describes something, someone and situation, or write about the way persons, places or things appear. In SMP Pemecutan Denpasar, descriptive text is taught by teacher in order to make students know how to describe themselves and their surrounding although it is still in a simple way. However, many students in seventh grade have difficulties in writing descriptive text because the teacher only explains what the generic structure and the method how to write the descriptive text, the teacher does not use any method or new ways to teach the students. Therefore, the students will be unmotivated, bored, and have difficulties in learning descriptive text. They also do not able to recall and to describe the things in a systematic order. Moreover, they cannot describe the parts, qualities, and characteristics of the things completely because what they are going to describe is abstract and they cannot imagine it in a short time.

Related with this problem, the new method of teaching writing especially for descriptive text is needed. Pictures can be used as a teaching media in teaching descriptive text. By using this media, students can observe the object which will be theme directly before writing it into paragraph. Students can describe and write the topic detailly and maximally. Peer assessment can be used as a method in teaching descriptive text too, because by observe their friend's work it can give some feedback and they can build constructive criticism, so that students are clear to make a descriptive text. Based on the background above, the main objective of this study is to figure out the application of pictures and peer assessment in writ- 
ing descriptive text and describe the improvement of students' achievement in writing descriptive text

\section{Definition of Descriptive Text}

Descriptive text is a kind of text with a purpose to give information. The context of this kind of text is the description of particular thing, animal, person, or others, for instance: our pets or a person we know well (Gerot and Wignell, 1994). Descriptive writing appeals to the senses, so it tells how something looks, feels, smells, tastes, and/ or sounds. In additon, a good description is like a "word picture"; the reader can imagine the object, place, or person in his or her mind. Regarding explanation above, in order to achieve its purpose, descriptive text has its own schematic structure and linguistic features, which will be discussed below.

Identification: the identification element aims at introducing and identifying specific participant (a person, thing, place, animal or event) to be described in the Descriptive text

Description: the description aims at describing the specific participant in text. It contains descriptive details or information of the specific participant by providing the description of its characteristics, appearances, personality, habits or qualities

Based on the definition of descriptive above it can be concluded that descriptive text is a part of factual genres. Its social function is to describe a particular person, place or thing. Description in writing is the process of creating visual images and sensory impression through words. More often, description is a part of another piece of writing is used to inform and audience about how something or someone looked or to persuade an audience to see

\section{Pictures}

The teaching and learning process is viewed as an integrated part. It means that the result of the teaching-learning process will be determined by the roles of all components involved. It also implies, for the teacher, that deciding what visual aids to be employed is one of the essential decisions that must be made in making an instructional design. Teaching aid or media is very needed in order to facilitate the teaching and learning process. Using instructional media is requiring creative efforts to overcome a variety of problems and help in achieving the instructional sub objectives of: (a) attractive attention; (b) developing interest; (c) adjusting the learning climate; (d) increasing understanding; (e) promoting acceptance (of an idea); (f) introducing hands on and interactive activities.

The pictures as an aid help the teacher to draw her students' interest and engage the students to be active during the teaching and learning process. The purpose of using media in the instruction is to assure that learners have meaningful experience. For this purpose, the teacher may use pictures in many stages of the instructional process to introduce and motivate study of new topics, to clarify conceptions and to communicate basic information (Brown et al, 1994:182). Furthermore experienced instructors find many valuable uses for still pictures. Research and experience show that:

a. Pictures stimulate students interest

b. Properly selected and adopted, pictures help readers to understand and remember the content of accompanying verbal materials.

c. Verbal and/or symbolic cueing of still pictures through use of arrows or other marks can clarify-or possibly change-the message intended to be communicated by them

\section{Peer Assessment}

Many definitions exist about what constitutes peer assessment. Peer assessment is a way for students to practice analyzing the work of others. Students learn to look critically at others' work and analyze it for strengths and weaknesses. They also deepen their understanding of their understanding of the expectations of each particular writing genre because they must know what a good topic sentence is if they are going to determine if their peer's work has an effective topic sentence (Brown, 1994). By using peer assessment teachers can also ask students to reflect on what they saw in their partner's work and choose an aspect that they might want to include in their own writing in the future. This should be a positive process, so provide explicit examples of feedback and constructive criticism so that students are clear on how they are to evaluate a classmate's work (Brown, 1994).

a. The students use rubrics format to correct the other's essay, especially on the element of grammar and structure and to give scores to peer's work. 
b. They discuss it in pairs/group

c. The teacher is a facilitator

\section{METHODS}

This study employed a classroom action research, which was targeted to develop a suitable technique to improve the writing ability of students in Grade $7^{\text {th }}$ at SMP Pemecutan Denpasar, which is consists of 17 students. This class were chosen as data source because based on the observation, the ability of students in this class were very lack in writing than the other skill. This school was chosen because of the position which is located at $\mathrm{Jl}$ Gunung Batur Gang Nangka Number 3 in Denpasar. Denpasar is well-known city in Bali. The techniques of collecting data in this study were derived from observation within the physical activity in the classroom, gave questionnaire and test in which the test consists of pretest and posttest. Qualitative and quantitative methods were used in analyzed the data. In this study, the data were analyzed based on criteria to assest the written language modified from analitic rubric proposed by Nurgiyantoro (2010) and Brown (2004) those are:

Table 1

Analytic Rubric for Written Language

\begin{tabular}{|c|c|c|}
\hline Aspects & Score & Criteria \\
\hline Content & $\begin{array}{c}16-20 \\
11-15 \\
6-10 \\
0-5\end{array}$ & $\begin{array}{l}\text { Main ideas state clearly and } \\
\text { accurately, change of opinion } \\
\text { relatively clear. } \\
\text { Main ideas somewhat unclear } \\
\text { and inaccurate change of opinion } \\
\text { somewhat weak. } \\
\text { Main ideas not clear or accurate, } \\
\text { change opinion weak. } \\
\text { Main ideas not at all clear or } \\
\text { accurate, change of opinion very } \\
\text { weak }\end{array}$ \\
\hline Organization & $\begin{array}{c}16-20 \\
11-15 \\
6-10 \\
0-5\end{array}$ & $\begin{array}{l}\text { Well organized and perfectly } \\
\text { coherent } \\
\text { Loosely organized but main ideas } \\
\text { clear, logical but incomplete } \\
\text { sequencing } \\
\text { Ideas disconnected, lacks logical } \\
\text { sequencing } \\
\text { No organization, incoherent }\end{array}$ \\
\hline Vocabulary & $\begin{array}{c}16-20 \\
11-15 \\
6-10 \\
0-5\end{array}$ & $\begin{array}{l}\text { Very effective choice of words } \\
\text { and use of idioms and words } \\
\text { forms. } \\
\text { Effective choice of words and } \\
\text { use of idioms and word forms. } \\
\text { Adequate choice of words but } \\
\text { some misuse of vocabulary, } \\
\text { idioms and word forms. } \\
\text { Limited range, confused use of } \\
\text { words, idioms and word forms. }\end{array}$ \\
\hline
\end{tabular}

\begin{tabular}{|c|c|c|}
\hline Grammar & $\begin{array}{c}16-20 \\
11-15 \\
6-10 \\
0-5\end{array}$ & $\begin{array}{l}\text { No errors, full control of } \\
\text { complex structure } \\
\text { Almost no error, fair control of } \\
\text { structure } \\
\text { Some errors, fair control of } \\
\text { structure } \\
\text { Many errors, poor control of } \\
\text { structure }\end{array}$ \\
\hline Mechanics & $\begin{array}{c}16-20 \\
11-15 \\
6-10 \\
0-5\end{array}$ & $\begin{array}{c}\text { Mastery of spelling and } \\
\text { punctuation } \\
\text { Few errors in spelling and } \\
\text { punctuation } \\
\text { Fair number of spelling and } \\
\text { punctuation errors } \\
\text { Frequent errors in spelling and } \\
\text { punctuation }\end{array}$ \\
\hline
\end{tabular}

After knowing the student's individual score continued by analyzed mean of students' score per action within one cycle by using the formula of Kemmis \& Mc. Taggart (1998) as below:

$$
\overline{\mathrm{X}}=\frac{\Sigma \mathrm{X}}{\mathrm{N}} \quad \begin{array}{ll}
\frac{\mathrm{X}}{\mathrm{X}} & \begin{array}{l}
\text { : mean } \\
\text { student's score }
\end{array} \\
\mathrm{N} & : \text { number of student } \\
\mathrm{N} & : \text { quantity }
\end{array}
$$

The passing score in SMP Pemecutan Denpasar for seventh grade is 70 . After analyzing the score of pre test and post test, the class percentage will analyzed by using the following formula (Sudijono, Anas (2003)

$$
P=\frac{R}{n} \times 100 \quad \begin{array}{ll}
\text { P: the class percentage } \\
\text { R: total students passed the KKM (up to 70) } \\
\text { n: number of students }
\end{array}
$$

Then, to know about student's level in writing descriptive text, the following Interval were used:

Table 2

The Level of Student's Mastery

\begin{tabular}{cc}
\hline Score Interval & Category \\
\hline $90-100$ & Excellent \\
\hline $80-89$ & Very Good \\
\hline $70-79$ & Good \\
\hline $51-69$ & Moderate \\
\hline $0-50$ & Poor \\
\hline \multicolumn{2}{c}{ Nasrun, Harahap (1982) }
\end{tabular}

Lastly, to get the improvement score from the pre-test up to posttest score in cycle it uses the formula:

$P=\frac{y 1-y}{y} \times 100 \% \quad \begin{aligned} & \begin{array}{l}\text { P: Percentage of student's improvement } \\ \text { y: Pre-test result } \\ \text { y1: post test }\end{array}\end{aligned}$

In conducting the research, researcher was assisted by a teacher who also taught English at SMP Pemecutan Denpasar as her collaborator. A collaborator has an important role in this 
research those are to observe the teaching and learning process, students' responses, the application of method, and anything that happened in the classroom. For the treatment, lesson action plans and handouts were given.

Classroom Action Research (CAR) in this research was done in two cycle process. Each cycle covers four steps; (1) planning, (2) acting, (3) observing, and (4) reflecting. Before doing cycle I, the researcher carried out pre-test to know the extent of students' speaking competency. After cycle I was accomplished, the researcher conducted cycle II. The complete elucidation can be seen as follows:

CYCLE I

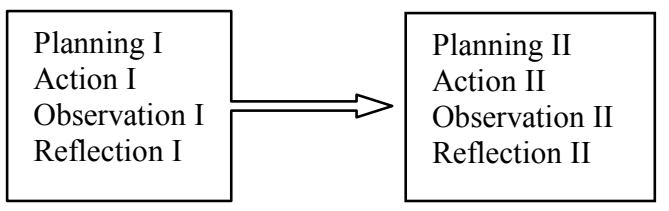

Histogram 1

The Procedure of Each Cycle

In the planning steps, some activities were planned like preparing a lesson plan, pictures and duration. In acting steps, the researcher teaches writing especially for description text by using pictures and combined it with peer assessment. In observing step, the researcher collected data about anything that happened in the process of teaching and learning including about the strength and the weakness of this method. To observe the data of students' mastery in writing description text, the researcher obtains from students' scores of writing test that was given for every single cycle and questioner. In reflecting steps, the researcher identifies the success of the implementation of the plan conducted in every cycle.

The analysis and reflection were used to know how was the student's improvement in writing activity especially for writing description text. The cycle would be stopped in condition the students have achieved the minimum score of this study is 70 . In order to get the data of writing description text, the researcher used the scoring criteria modified from analitic rubric proposed by Nurgiyantoro (2010) and Brown (2004) which is consist of organization, content, vocabulary, grammar and mechanics. The data, which were taken from the results of performance tests, were called quantitative data and analyzed by descriptive analysis; whereas the data taken from questionnaires and observation sheet were called qualitative data.

\section{DISCUSSION}

\section{Identification Problem}

Based on the observations, the researcher found several problems in teaching and learning process of writing descriptive text in this class. The field problems presented as Table below.

Table 3

The Field Problems in Teaching and Learning Writing

\begin{tabular}{ll}
\hline Problems & Actions \\
\hline $\begin{array}{l}\text { There was not any media in } \\
\text { teaching and learning } \\
\text { process, make the students } \\
\text { easily felt bored and had } \\
\text { low motivation to learn. }\end{array}$ & $\begin{array}{l}\text { Using Pictures as media to } \\
\text { get the students attention } \\
\text { and motivation also }\end{array}$ \\
\hline $\begin{array}{l}\text { The students lacked in ideas } \\
\text { and vocabulary so that they } \\
\text { considered writing was } \\
\text { difficult }\end{array}$ & $\begin{array}{l}\text { Using Pictures as media to } \\
\text { help the students in } \\
\text { developing idea and have } \\
\text { an imagination about the } \\
\text { vocabulary }\end{array}$ \\
& $\begin{array}{l}\text { Peer assessment and give } \\
\text { feedback to the students } \\
\text { feedback from teacher }\end{array}$ \\
\hline
\end{tabular}

The Application of Pictures and Peer Assessment in Writing Class

This research was conducted in addition to improve the ability of students in writing descriptive text. Before the treatment is given, pre test was conducted. In this test, the students have to make a descriptive text consists of two paragraphs with topic "My School". The data on student's achievement score in pre test were presented as table below:

Table 4

Student's Score Frequency in Pre Test

\begin{tabular}{ccc}
\hline Interval & Frequency & Percentage (\%) \\
\hline $90-100$ & 0 & 0 \\
\hline $80-89$ & 0 & 29,4 \\
\hline $70-79$ & 5 & 29,4 \\
\hline $51-69$ & 5 & 41,6 \\
\hline $0-50$ & 7 & 0 \\
\hline Total & $\mathbf{1 7}$ & $\mathbf{1 0 0}$
\end{tabular}

The minimum mastery criterion (KKM) in this school is 70 . From the data above it was found that the highest score of student's ability in writing descriptive text is in interval score 70 -79 and the lowest score in interval score 0-50. 
Mean of the class in pre test is 58 . There are 5 students $(29,41 \%)$ who passed the KKM and there are 12 students $(70,58 \%)$ did not pass it. Poor level is dominant in pre test. There were some students had not finished yet their test, it may be caused the students had not been ready to learn descriptive text.

After found this result, the treatment is given in this class. The treatment in cycle one conducted in three meetings. First meeting, the writer implemented the teaching learning process based on the lesson plan had been made, and start the class by giving explanation of descriptive paragraph, the criteria of writing assessment, and how to make a paragraph by using pictures. The writer continued the class and gave the example how to make descriptive paragraph by using pictures. Afterward they practice to make descriptive paragraph together and submitted it. Second meeting, the writer introduced peer assessment to the class. After that distributed student's work to the other students. The next step, the writer asked them to read their friend's work and find the mistakes, make some corrections, and gave point based on the rubric that has explained before. After all students submitted their work, the writer discussed it one by one in front of the class. Third meeting, the writer gave the post test to the students. The writer provided the topic "My Lovely School: SMP Pemecutan Denpasar", and pictures that supported this topic to the students then asked them to make a descriptive paragraph. After submitted their paragraph, then it distributed to the other students and they have to make an assessment about their friend work in comments column. The comments related about the rubric of writing that given in second meeting. After finish and submitted it, the researcher then discussed the test with the students and evaluated the most students' error. The usage of peer assessment in post test cycle one is to know about students understanding in learning and teaching process in the class. The result of pre test can be seen in the table below:

Table 5

Student's Score Frequency in Post Test Cycle 1

\begin{tabular}{ccc}
\hline Interval & Frequency & Percentage (\%) \\
\hline $90-100$ & 0 & 0 \\
\hline $80-89$ & 2 & 11,76 \\
\hline $70-79$ & 10 & 58,8 \\
\hline $51-69$ & 5 & 29,4 \\
\hline $0-50$ & 0 & 0 \\
\hline Total & $\mathbf{1 7}$ & $\mathbf{1 0 0}$ \\
\hline
\end{tabular}

From the data above it was found that the highest score of student's ability in writing descriptive text is in interval score $80-89$ and the lowest score in interval score 51-69. Good level is more dominant in this test. Mean of the class in post test cycle one is 71 . There are 12 students $(70,58 \%)$ were passed the KKM and there are 5 students $(29,41 \%)$ did not pass the KKM. Then the percentage of student's improvement score from pre test into post test cycle one is $69,58 \%$. It showed that there were some students who were not ready to learn writing using pictures and peer assessment. There were some students still did not understand how to make descriptive text by using pictures. It may be caused that they still did not know how to combine all of the pictures becomes a descriptive text. Based on the comments in peer assessment, there were some students having a problem in grammar. Here is the example of student's work in Pre test, Post Test 1 and the comments of peer assessment.

\section{Pre Test 'S10'}

My Lovely School

My school is big my school consist of there office, office head school, teacher, library, field basket, temple. my school very cool, canten my school clean, crowded moment in break. My school have library, we can read book, librray prepare various kind book, my school have room computer, office head school teacher hall, bathroom.

\section{Researcher Comments:}

The words in italics above show about the mistake of this work. Based on the rubric for written language, this work must be analyzed from the five aspects in written language, those are from the content, organization, vocabulary, grammar and mechanic. Talking about the content, this work has got 13 point because main idea too weak and unclear topic clearly, and there still found repetition object. Based on the organization it has got 10 point because of disconnect idea and the number of sentence in composing the paragraph less than six sentences. Based on the vocabulary it has got 12 point because there are some misuse of vocabulary. Based on the grammar it has got 10 point because there are some errors and fair control of structure. For the mechanism it has got 10 point because there are some punctuation errors. The total point of this work 
is 55 .

\section{Post Test 1 'S10'}

My Lovely School

My school is big. It consists of classroom here are, class seven, class eight and class nine. My class is located in the canteen and office. There are headmaster room and teacher room. There are bathroom students and teacher. There are supervisor room.

In my school, there is library. It consists of book like, story book, biology book, English book and mathematic book. There are canteen sell noodle, snack, yellow rice candy and friend rice. I and my friend like noodle. My school has two temple.

\section{Peer Assessment from 'S02':}

The first sentence too short. Second sentence is wrong it must be "It consists of 3 classrooms there are, seven classroom, eight classroom and nine classroom". Head master office not room. In paragraph two line four, the word friend rice must be fried rice. Temple must be plural becomes temples. The use of punctuation like comma and full stop need revised.

\section{Researcher Comments:}

'S10' wrote a good description. She wrote a description text based on the picture but there still several mistake that can be seen in bold and italics type above. Based on the rubric for written language, she got 16 for the content, because she can explain her main idea clearly, and she change opinion clearly. She organized her writing pretty good and she got 15 point. There is an increasing number of sentence in composing the paragraph than her work in pre test. Based on the vocabulary it has got 12 point because there still wrong verb or other class word used in her work. For the example when she wrote class seven, class eight and class nine it supposed to be $7^{\text {th }}$ class, $8^{\text {th }}$ class and $9^{\text {th }}$ class.

She wrote Head master room which is the correct one is Head Master's Office but is better than her work in pre test that used "head school". On the other side the good point of her, she used conjunction. Based on the grammar it has got 12 point because there are some errors and fair control of structure. She put wrong grammar in sentences, for the example "It consists of " must be adding to be becomes "It is consists of". For the mechanic it was better than before and she has got 15 point because there are some punctuation errors. The total point of this work from researcher is 70 . Talking about the process of peer assessment which is conducted by S02, almost gave a correct assessment and this comments will help S10 to improve her writing ability.

After observing the reflecting phase above, there must be more efforts to develop students' writing skill of descriptive text by using pictures and peer assessment. It needed to be improved again in the next cycle. The writer needed to motivate the students and to explain again about how to make descriptive paragraph by using pictures and learn from the comments of their friends in peer assessment, so they can make descriptive text in properly.

Cycle two consists of two meetings; on the first meeting the students were motivated in making descriptive text only based on the pictures and they have to remind about the correction of their friends in peer assessment. On the second meeting, they have a post test and the topic is similar with post test in cycle one. The result of post test in cycle two can be seen as follow:

Table 6

Student's Score Frequency in Post Test Cycle 2

\begin{tabular}{ccc}
\hline Interval & Frequency & $\begin{array}{c}\text { Percentage } \\
(\mathbf{\%})\end{array}$ \\
\hline $90-100$ & 0 & 0 \\
\hline $80-89$ & 5 & 29,41 \\
\hline $70-79$ & 12 & 70,5 \\
\hline $51-69$ & 0 & 0 \\
\hline $0-50$ & 0 & 0 \\
\hline Total & $\mathbf{1 7}$ & $\mathbf{1 0 0}$ \\
\hline
\end{tabular}

From the data above it was found that the highest score of student's ability in writing descriptive text is in interval score $80-89$ and the lowest score in interval score 70-79. Mean of the class in post test is 77 . Although there is not a high increase in level of student's mastery which is still in good level, but all of students those are 17 students $(100 \%)$ were passed the KKM. Then the percentage of student's improvement score from pre test into post test cycle one is $99 \%$.

Based on the discussion above, it was found an improvement of mean class in every action that can be seen as below: 
Table 7

The Improvement of Mean of The Class

\begin{tabular}{ccc}
\hline Types of Test & Mean Score & Category \\
\hline Pre Test & 58 & Moderate \\
\hline Cycle 1 & 71 & Good \\
\hline Cycle 2 & 77 & Good \\
\hline
\end{tabular}

In details, mean of the class from pre test is 58 has a slightly improvement becomes 71 in cycle one and 77 in cycle two. Besides the product there also an improvement from the quality of student's work and peer assessment process in cycle two that can be seen as below:

\section{Post Test 2 'S10'}

\section{My Lovely School}

My school is big. It consists of three classroom those are, classroom for eight class, for seven class and nine class. My class is located near the canteen and office teacher. Besides that, there are headmaster's office and teacher office too. There are different bathroom for students and teacher. In my school, we can do supervising in supervisor room.

In my school, I usually read book in library. There many kinds of book ever there like, story book, biology book, English book and mathematic book. Besides that there are two computers. When I'm hungry, I go to canteen, it sell noodle, snack, yellow rice, candy and fried rice. I and my friend like eat noodle. There is two temples in my school.

\section{Peer Assessment from 'S08':}

This work almost correct. The mistakes just from vocabulary and mechanics. For the vocabulary, can be seen from the word "mathematic" must be written into "mathematics" because it is a subject. For the mechanics this work have mistakes about the punctuation.

\section{Researcher Comments:}

'S10' has a good description text in post test 2 . She wrote a clearly description about the picture although there still several mistake that can be seen in bold and italics typing style above. Based on the rubric for written language, this work got 20 for the content, because she can explain her main idea clearly. She organized her writing very well and she got 14 point. She added a good introduction and closing. There is a consistent number of sentence in each paragraph than her work in pre test and post test 1 . She add more vocabularies in her work and she has got 16 point. There still found the similar mistake from previous test, those are when she wrote classroom for eight class, for seven class and nine class, it supposed to be $7^{\text {th }}$ class, $8^{\text {th }}$ class and $9^{\text {th }}$ class. One of the good point of her, she used conjunction. Based on the grammar it has got 15 point because there are almost no errors and there is a fair control of structure. She used present tense mostly for the grammar. Mechanic aspect was better than before and she has got 15 point because there is no errors. The total point of this work from researcher is 80 . Talking about the process of peer assessment which is conducted by ' $\mathrm{S} 08$ ' is very useful for the improvement of 'S10' in writing class. Peer assessment is very effective to be applied in teaching and learning descriptive text because it automatically make the students remember about the structure of the text.

Based on the observation in reflective phase, there are different result from pre test, post test cycle one and post test cycle two. The students who has a low score in pre test has a good improvement in post test cycle one and post test cycle two. This might be the result of four process in every cycle, those are planning, action, observation and reflection. It can be concluded that the application of pictures and peer assessment can motivate students in improving their writing skill. The summary of student's ability in writing descriptive text can be seen as follows:

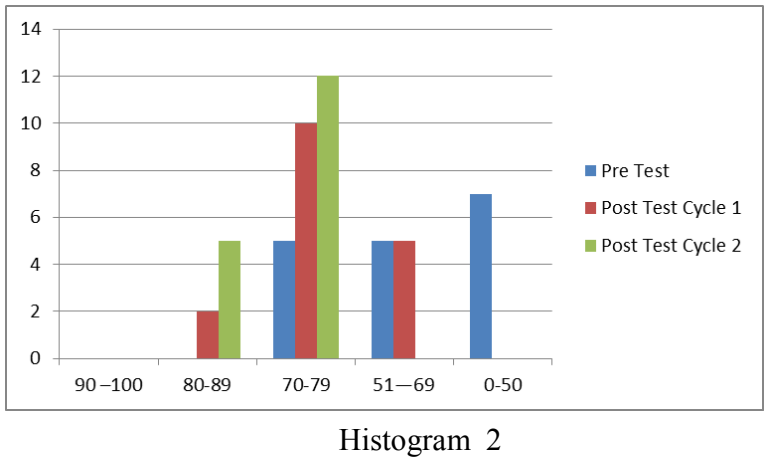

The Improvement of Students' Score In Pre Test, Post Test Cycle 1 and Cycle 2

According to the Histogram above, the bars is go up in every cycle. It means that there are a good improvement of students. From 17 students that have been chosen as data source, in pre test, there are seven students got score in 
interval 0-50, 5 students are in interval 51-69 and 5 students also in interval 70-79 and there is no one got score above 80 . In cycle one, there is no one get score in interval $0-50$. There are 5 students in interval 51-69. There are 10 students has a score in interval 70-79. Lastly, there are two students has a score in interval 80-89.

In cycle two, there are a slightly improvement because there is no student has a score in interval 0-50 and 51-69. There are twelve students got score in interval 70-79, and the rest 5 students are in interval 80-89. In this cycle the treatment is stop given in this class because from the result, all of the students has reached score above 70 as the minimum mastery criterion (KKM) in this school. Mean class already passed the KKM and the level of student's mastery in cycle two is good.

The other success of this treatment can be seen from the process of teaching and learning in the class. As mentioned in research method, the data was also gained from questionnaires. The questionnaire are talking about the method of teaching and learning writing description text. The result can be seen as below:

Table 8

Pre Test Questionnaire Result

\begin{tabular}{clcc}
\hline No & \multicolumn{1}{c}{ Question } & \multicolumn{1}{c}{ Yes } & No \\
\hline 1 & $\begin{array}{l}\text { Do you know what is a } \\
\text { descriptive text? }\end{array}$ & $4(23.52 \%$ & $13(76,47 \%)$ \\
\hline 2 & $\begin{array}{l}\text { It is easy to make a } \\
\text { descriptive text? }\end{array}$ & $2(11,76 \%)$ & $15(88,23 \%)$ \\
\hline 3 & $\begin{array}{l}\text { Do you know about the } \\
\text { aspect of assessment in } \\
\text { written language? }\end{array}$ & \\
\hline 4 & $\begin{array}{l}\text { Do you think that the } \\
\text { method of your }\end{array}$ & & \\
& $\begin{array}{l}\text { English teacher is } \\
\text { effective in learning } \\
\text { descriptive text? }\end{array}$ & & \\
\hline 5 & $\begin{array}{l}\text { Do you enjoy and } \\
\text { understand learning } \\
\text { descriptive text with } \\
\text { the old method from } \\
\text { your teacher? }\end{array}$ & \\
\hline
\end{tabular}

According to the result of pre test questionnaires on the table 8 above, there are only $23,52 \%$ of the students know about descriptive text and the rest $76,47 \%$ of students did not know about this type of the text. It might be happen because the students are not focused on the teaching and learning process in the class. Next question talking about their ability in making descriptive text, there are $11,76 \%$ of students claimed that it is easy to make a descriptive text and the rest of students
$88,23 \%$ claimed that it is not easy to make a descriptive text because they did not know how to make it and what are the components that should be there in descriptive text. This reason related with the next question that are talking about the assessment of written language. The result of this causes make the same opinion with the previous questions. The next questions are talking about the method of English teacher in teaching descriptive text. There are only $23,52 \%$ of students stated that the old teacher from method can help them in making descriptive text, and for the rest of students $76,47 \%$ stated that the learning method is not effective because the method is teacher centered. The effect of this method make they did not interested to the writing class especially for making descriptive text. It is related with the last question of the questionnaires. Only $11,76 \%$ of students stated enjoyed in the class and the rest $88,23 \%$ of students did not feel enjoy and understand with the method of the teacher in the learning and teaching process. By this questionnaires, the researcher can identify the problems of the class and suggest a treatment to reduce the problems in writing descriptive text.

The questionnaire were given also in cycle two to know the opinion of students after the treatment. The result can be seen as the table below:

Table 9

Post Test Questionnaire Result

\begin{tabular}{|c|c|c|c|}
\hline No & Question & Yes & No \\
\hline 1 & $\begin{array}{l}\text { Do you think pictures can } \\
\text { stimulate you to have an } \\
\text { idea in making descriptive } \\
\text { text? }\end{array}$ & $\begin{array}{c}15 \\
(88,23 \%)\end{array}$ & $2(11,76 \%)$ \\
\hline 2 & $\begin{array}{l}\text { Do you think by assessing } \\
\text { your friend's work makes } \\
\text { you easier to remember } \\
\text { the } \\
\text { components? }\end{array}$ & $\begin{array}{c}16 \\
(94,11 \%)\end{array}$ & $1(5,8 \%)$ \\
\hline 3 & $\begin{array}{l}\text { Do you feel easier to } \\
\text { make descriptive text from } \\
\text { the pictures and doing } \\
\text { peer assessment? }\end{array}$ & $\begin{array}{c}17 \\
(100 \%)\end{array}$ & $0(0 \%)$ \\
\hline 4 & $\begin{array}{l}\text { Do you think that the } \\
\text { combination of pictures } \\
\text { and peer assessment are } \\
\text { effective in learning } \\
\text { descriptive text? }\end{array}$ & $\begin{array}{c}17 \\
(100 \%)\end{array}$ & $0(0 \%)$ \\
\hline 5 & $\begin{array}{l}\text { Do you think your } \\
\text { knowledge about writing } \\
\text { descriptive text is } \\
\text { increased by doing } \\
\text { combination of pictures } \\
\text { and peer assessment? }\end{array}$ & $\begin{array}{c}17 \\
(100 \%)\end{array}$ & $0(0 \%)$ \\
\hline
\end{tabular}

Based on the result of post test questionnaires on the table 9 above, there are 
$94,11 \%$ of the students stated that pictures can stimulate them to have an idea in making descriptive text. The same number of students $(94,11 \%)$ also stated that peer assessment make them easier to remember the descriptive components, like the content, organization, vocabulary and mechanism. All of the students $(100 \%)$ agreed that the implementation of pictures and peer assessment make them easier in writing descriptive text. All of the students $(100 \%)$ also agreed that the implementation of pictures and peer assessment very effective in learning process. All of the students $(100 \%)$ stated that their knowledge in writing descriptive text is increased by doing the combination of pictures and peer assessment. They fell their knowledge was increased because by assessing their friend's work they can learn directly from the right structure of their friend's work and fix the wrong structure of their work from friend's comment. It can increased their creativities also.

\section{CONCLUSION}

Based on the research which is conducted in seventh grade of SMP Pemecutan Denpasar, it can be concludes that the implementation of pictures and peer assessment in writing class can help students in improving their ability and motivation to make a descriptive text. It can be seen from the improvement of students score in each test. Mean score for pre test is 58 and from this test there are 5 students $(29,41 \%)$ who passed the KKM. Meanwhile, mean score for post test cycle one is 71 and there are 12 students $(70,58 \%)$ who passed the KKM. Mean score in post test cycle two is 77 and all of the students passed the KKM. Related to the teaching and learning process, after conducted this method, there is a positive attitude from the students toward the class. By using this method the students seem more enthusiastic to follow the class. There is no student absent on writing class. Their curiosity about the picture can be shown from their face when the researcher showed it one by one.

Pictures can help them to find the main idea and develop it into paragraph. The ability of mastering vocabularies and expressing an opinion was increased after they had a peer assessment. The result of test and questioner support this statement. All students agreed that the implementation of pictures and peer assessment are effective in increasing their writing skill especially for write descriptive text. They also said that pictures can stimulate them to have an idea and increased their ability in mastering vocabulary. Peer assessment can help them to share their knowledge to other friends directly by assessing their friend's work, for the example learn about grammar and mechanism of writing technique. They can learn directly from the right structure of their friend's work and fix the wrong structure of their work from friend's comment. It can increased their creativities also.

\section{ACKNOWLEDGMENT}

In this session I would like to give my deepest appreciation for the reviewer. Thank you for the critic and suggestion to make this article better.

\section{REFERENCE}

Brown, H. Douglas. 1994. Teaching By Principles: an interactive approach to language Pedagogy. USA: Prentice-Hall, Inc.

Catharina, Tri Anni. 2009. Psikologi pendidikan. Semarang: UNNES

Enre, Fachruddin Ambo. 1988. Dasar-Dasar Keterampulan Menulis. Jakarta: Depdikbud.

Gie, The Liang. 2002. Terampil Mengarang. Yogyakarta: Andi.

Gerot, Linda dan Wignell Peter (Eds). 1994. Making Sense of Functional Grammar. Sydney: Antipodean Educational Enterprises.

Hamdani. 2011. Strategi Belajar Mengjara. Bandung: Pustaka Setia.

Iskandarwassid dan Dadang Sunendar. 2008. Strategi Pembelajaran Bahasa. Bandung: PT Remaja Rosdakarya.

Keraf, Gorys. 1981. Deskripsi dan Deskripsi. Flores: Nusa Indah.

Nurgiyantoro, Burhan. 2013. Penilaian Pembelajaran Bahasa Berbasis Kompetensi. Yogyakarta: BPFE.

Nasrum, Harahap. Teknik Penilaian Hasil Belajar. 1982

Nurgiyantoro, Burhan. 2010. Teori Pengkajian Fiksi. Yogyakarta: Gadjah Mada University Press.

Press. Darmadi, Kaswan. 1996. Meningkatkan Kemampuan Menulis. Yogyakarta

Suprijono, Agus. 2009. Cooperatif Learning: Teori dan Aplikasi, Yogyakarta: Pustaka Pelajar.

Sudijono, Anas. 2003. Pengantar Statistik Pendidikan. Jakarta: Raja Grafindo Persada.

Sutrisno. 2012. Pembelajaran Fluida dengan 
Menggunakan Model Jigsaw dengan Peer Assessment untuk Meningkatkan Keterampilan, SIkap Ilmiah, dan Prestasi Belajar Siswa Kelas XI IPA. Journal of Innovative Science Education, 1(1): 10:13

Tarigan,Henry Guntur. 2008. Menulis sebagai
Suatu Keterampilan Berbahasa. Bandung: Angkasa.

Wahyuni, Sri dan Syukur Ibrahim. 2012. Assesmen Pembelajaran Bahasa. Bandung: Refika Aditama. 